\title{
O Cuidar e o ser cuidado na prática dos operadores de saúde
}

O cuidado pertence à essência do humano e de tudo o que existe e vive.

Tal verdade foi expressa exemplarmente pelo famoso mito do cuidado que nos vem da tradição romana (do escravo Higino, fábula no 220). Esse mito constitui o núcleo central da obra maior de Martin Heidegger Ser e Tempo ${ }^{1}$. Aí aparece claro que não é o espírito, a liberdade ou a criatividade que constituem a essência do ser humano. Essa essência reside no cuidado, aquela condição prévia que precisa ocorrer para que qualquer ser, mas especialmente o ser humano, possa irromper na existência. Foi pelo infinito cuidado de nossas mães que nós, sem nenhum órgão especializado, conseguimos viver e sobreviver. Deixados no berço, não saberíamos procurar o alimento necessário e morreríamos².

Tudo o que fazemos vem, pois, acompanhado de cuidado. Tudo o que amamos também cuidamos. Tudo o que cuidamos também amamos. O cuidado é tão essencial que é por todos compreendido. Porque todos o experimentamos a cada momento seja ao andar na rua, seja dirigindo o carro e seja na relação para com os doentes confiados ao corpo médico.

Três sentidos básicos são expressos pelo cuidado. Ele significa, primeiramente, uma relação amorosa, suave, amigável e protetora para com os enfermos. Num sentido mais amplo, o cuidado é visto como um novo paradigma. Ele se confronta com o paradigma da modernidade que reside na vontade de poder como dominação, como uma mão que agarra e se apropria. Contrariamente, o cuidado é a mão que acaricia e acolhe.

Em segundo lugar, o cuidado é todo tipo de envolvimento que possuímos com os doentes face aos quais, de certa forma, devotamos empatia e vontade de curar.

Vera Regina Waldow, uma enfermeira que soube unir uma vasta experiência com uma segura reflexão teórica escreveu: "Os objetivos de cuidar envolvem, entre outros, aliviar, confortar, ajudar, favorecer, promover, restabelecer, restaurar, dar, fazer. O cuidado mesmo na ausência de alguma enfermidade e no cotidiano dos seres humanos, é também imprescindível, tanto como uma forma de viver como de se relacionar"3(p.89).

Uma terceira dimensão do cuidado é a que liga os seres humanos ao planeta Terra. A partir da visão dos astronautas que puderam ver a Terra de fora da Terra, ficou claro que Terra e Humanidade formam uma única entidade, como um todo vivo e orgânico. A Terra é viva. Nós somos aquele momento de sua alta complexidade que começou a sentir, a pensar, a amar e a cuidar. Somos Terra, pois homem (ser humano) vem de húmus, terra fértil e fecunda. Há uma relação tão estreita entre nós e a Mãe Terra que se nós a fazemos adoecer, superexplorando-a, nós mesmos adoecemos. E quando adoecemos, afetamos também a saúde da Terra. Há, pois, uma comunidade de destino comum entre nós e a Terra.

Unindo os três sentidos aqui aportados, podemos dizer que a atividade médica e de todos os profissionais de saúde emerge também como uma atividade política e ecológica, de cuidado e salvaguarda da Terra e, com ela, das vidas humanas e de toda a comunidade de vida.

Eis que se levanta uma questão: quem cuida do cuidador? Como todos os seres humanos, os operadores da saúde estão sujeitos às limitações da condição humana, vigorosa e frágil, saudável e doentia, psicologicamente forte e débil. Eles também sentem a necessidade do cuidado. Quem cuida do cuidador? É uma equipe de médicos/as e enfermeiros/as que se articulam para dar suporte humano ao companheiro ou companheira sob estresse. Cuidar não é um ato, mas uma atitude permanente e, não raro, desgastante. Esse cuidado empático reanima a pessoa que volta a exercer o seu trabalho/missão com senso da ética do cuidado.

Leonardo Boff (https://orcid.org/0000-0001-7633-3360) ${ }^{1}$

${ }^{1}$ Universidade do Estado do Rio de Janeiro. Rio de Janeiro RJ Brasil.

\section{Referências}

1. Heidegger M. Ser e tempo. Petrópolis: Editora Vozes; 1989.

2. Boff L. Saber cuidar. Petrópolis: Editora Vozes; 1999.

3. Waldow VR. Cuidar: expressão humanizadora da enfermagem. Petrópolis: Editora Vozes; 2006. 